\title{
ANALISIS KORELASI PENGETAHUAN TENTANG SENAM HAMIL DENGAN MINAT IBU HAMIL DALAM MELAKUKAN SENAM HAMIL
}

\section{THE CORRELATION OF KNOWLEDGE ABOUT PRENATAL EXCERCISE TO PREGNANT WOMEN'S INTEREST IN DOING PRENATAL EXCERCISE}

\author{
Vide Bahtera Dinastiti ${ }^{1}$, Ratna Feti Wulandari ${ }^{2}$, Ratih Kusuma Wardhani ${ }^{3}$ \\ 1,2,3, STIKes Pamenang \\ *Korespondensi penulis : videsakti1987@gmail.com
}

\begin{abstract}
Abstrak
Kegiatan prenatal yang bermanfaat bagi ibu hamil yaitu senam hamil yang merupakan bentuk antenatal care dalam rangka menurunkan angka kematian ibu di Indonesia. Ibu hamil yang melakukan senam hamil secara teratur dapat memperpendek pada masa kala aktif, menurunkan angka kejadian sectio cesaria serta mencegah terjadinya letak sungsang. Salah satu faktor yang mempengaruhi minat melaksanakan senam hamil adalah pengetahuan. Tujuan penelitian untuk menganalisis korelasi pengetahuan tentang senam hamil dengan minat ibu hamil dalam melakukan senam hamil. Desain penelitian yang digunakan analitik korelasi dengan pendekatan cross sectional. Pengambilan data dilakukan dengan menggunakan kuesioner. Variabel independen adalah pengetahuan tentang senam hamil sedangkan variabel dependen adalah minat ibu hamil dalam melakukan senam hamil. Sampel dalam penelitian adalah semua ibu hamil trimester II dan III dengan jumlah 30 responden yang diambil dengan teknik accidental sampling. Analisa data yang digunakan yaitu menggunakan uji Rank Spearman. Hasil penelitian didapatkan $\mathrm{p}<\alpha, \mathrm{p}=$ $0,010<0,05$ dan $r=0,461$ maka ada korelasi positif sedang antara pengetahuan dengan minat ibu hamil dalam melakukan senam hamil. Ibu hamil yang berpengetahuan baik sebagian besar berpendidikan cukup tinggi dan usia produktif maka memiliki minat yang baik untuk melakukan senam hamil. Kesimpulannya berarti semakin baik pengetahuan ibu hamil tentang senam hamil maka semakin berminat dalam melakukan senam hamil. Agar menarik minat ibu hamil dalam mengikuti senam hamil maka bidan dapat lebih aktif memberikan informasi tentang manfaat senam hamil dimulai pada saat ibu hamil melakukan pemeriksaan Antenatal Care pada trimester II yang akan meningkatkan pengetahuan ibu hamil serta memperlancar persalinan fisiologis.
\end{abstract}

Kata Kunci : Pengetahuan, Senam Hamil, Minat, Ibu Hamil

\begin{abstract}
Prenatal activities that are beneficial for pregnant women is prenatal exercise which is antenatal care in order to reduce maternal mortality in Indonesia. The exercise therapy is given to pregnant women with the aim of achieving a fast, easy and safe labor. One of the factors that influence the interest in doing prenatal exercise is knowledge. This study aims to determine the correlation between knowledge of prenatal exercise and interest of pregnant women in doing prenatal exercise. Design of the research was correlation analytic with cross sectional approach. Data were collected by questionnaires. The independent variable in this study is knowledge of prenatal exercise, while the dependent variable is interest of pregnant women in doing prenatal exercise. The sample in this study were all pregnant women in the second and third trimesters with a total of 30 respondents who were taken by accidental sampling technique. The data analysis used is the Rank Spearman test. The results showed that $p<\alpha, p=0.010<0.05$ and $r=0.416$, so there was a moderate positive relationship between knowledge and the interest of pregnant women in doing prenatal exercise. Most of the well-informed pregnant women are highly educated and productive age so they have a good interest in doing prenatal exercise. The conclusion of this study means that the better the knowledge of pregnant women about prenatal exercise, the more interested in doing prenatal exercise. In order to attract pregnant women to participate in prenatal exercise, midwives
\end{abstract}


can be more active in providing information about the benefits of prenatal exercise started from Antenatal Care examination in the second trimester which will increase the knowledge of pregnant women and facilitate physiological labor.

Keyword: Knowledge, Prenatal Excercise, Interest, Pregnat Women

\section{PENDAHULUAN}

Kegiatan prenatal yang bermanfaat bagi ibu hamil yaitu Kelas Ibu Hamil. Tujuannya adalah untuk meningkatkan pengetahuan dan keterampilan ibu hamil mengenai kehamilan, persalinan, perawatan nifas dan perawatan bayi baru lahir sehingga akan meningkatkan persalinan ke tenaga kesehatan dan menurunkan angka kematian ibu dan Anak (Kementerian Kesehatan Republik Indonesia, 2014)

Upaya menurunkan angka kematian ibu di Indonesia pada dasarnya mengacu pada empat pilar safe motherhood. Pilar kedua safe motherhood yaitu Ante Natal Care (ANC) dimana asuhan yang diberikan meliputi timbang berat badan, ukur tekanan darah, ukur tinggi fundus uteri, pemberian imunisasi TT (Tetanus Toksoid) lengkap, pemberian tablet zat besi, tes terhadap penyakit menular seksual, temu wicara dalam rangka persiapan rujukan, serta latihan senam hamil (Juaria, 2018).

Studi pendahuluan yang dilakukan peneliti di dapatkan hasil dari 10 ibu hamil, 4 ibu hamil yang berminat untuk melakukan senam hamil, karena ibu menganggap bahwa senam hamil bermanfaat untuk melatih pernafasan, menenangkan hati dan pikiran sehingga ibu tidak stress dan bayi juga tidak stress dan 6 ibu hamil kurang berminat untuk melakukan senam hamil karena rumah ibu yang jauh dari tempat pelayanan kesehatan, rasa malas dan tidak adanya keinginan untuk melakukan senam hamil.

Senam hamil merupakan senam yang dilaksanakan saat seorang ibu hamil dimana tujuannya adalah untuk mempersiapkan fisik dan mental ibu hamil sehingga diharapkan proses persalinan dapat berjalan dengan aman dan lancar. Selain itu, laporan hasil menyatakan bahwa ibu hamil yang melakukan senam hamil secara teratur dapat memperpendek pada masa kala aktif (kala II), menurunkan angka kejadian sectio cesaria serta mencegah terjadinya letak sungsang (Supriatmaja, dalam Septiani, 2019). Hal ini didukung dengan penelitian Masrurin (2012) yang menyebutkan bahwa senam hamil memberikan manfaat antara lain dapat menurunkan kejadian partus lama, inersia uteri, malpresentasi dan persalinan dengan tindakan.

Harapan dengan melakukan senam hamil yaitu akan memberi manfaat dalam membantu kelancaran proses persalinan, diantaranya dapat melatih pernapasan dan relaksasi, menguatkan otot-otot panggul dan perut, serta melatih cara mengedan yang benar. Kesiapan ini merupakan bekal penting bagi calon ibu saat persalinan (Jannah, 2012).

Data (PWS KIA) jumlah ibu hamil pada tahun 2019 di Puskesmas Kayen Kidul sebanyak 146 orang ibu hamil, setiap minggunya yang mengikuti senam hamil ratarata ada $11 \mathrm{ibu}$ hamil. Alasan dari sebagian ibu hamil yang tidak mengikuti senam hamil dikarenakan malas, tidak ada keinginan dan motivasi baik dari diri sendiri, suami maupun keluarga untuk melakukan senam hamil.

Notoatmodjo (2010) mengungkapkan bahwa pengetahuan adalah hasil dari tahu dan terjadi setelah seseorang melakukan pengindraan terhadap suatu objek. Pengetahuan juga dapat diperoleh dari pengalaman belajar dari pendidikan formal dan non formal. Sedangkan minat adalah suatu fungsi jiwa untuk dapat mencapai sesuatu (Purwanto, 2011). Minat mempunyai pengaruh yang besar terhadap perilaku karena dengan minat seseorang akan melakukan sesuatu akan melakukan sesuatu yang diminatinya. Hurlock (2012) menyebutkan bahwa faktor-faktor yang mempengaruhi minat antara lain : pendidikan, umur, pekerjaan, pengalaman, tanggung jawab, dan informasi. Bila seorang ibu hamil menyadari bahwa senam hamil adalah penting untuk menuju kelahiran kehamilanya itu memberikan rasa nyaman dan mengatasi keluhan yang dirasakan kemungkinan besar ia akan keluar untuk mempelajari dan mengikuti senam hamil.

\section{METODE}


Desain penelitian yang digunakan dalam penelitian ini adalah penelitian analitik korelasional dengan menggunakan metode pendekatan cross sectional. Penelitian ini dilaksanakan pada bulan April-Mei 2019 di PMB Lilik Muhibah, S.ST di Desa Sekaran Kec Kayen Kidul Kab Kediri.

Variabel independen dalam penelitian adalah pengetahuan ibu hamil tentang senam hamil sedangkan variabel terikatnya adalah minat ibu hamil dalam melakukan senam hamil. Populasi dalam penelitian ini adalah Seluruh Ibu Hamil yang periksa di PMB Lilik Muhibah,S.ST pada bulan April dan Mei. Pada penelitian ini sampel yang diambil adalah Ibu hamil Trimester II dan TM III dengan kriteria Ibu hamil yang bersedia diteliti, Ibu hamil TM II dan TM III dan Ibu hamil yang belum pernah melakukan senam hamil, yakni sebanyak 30 orang. Teknik sampling yang digunakan dalam penelitian ini adalah accidental sampling.

Pengambilan data dilakukan dengan menggunakan kuesioner pada ibu hamil yang memenuhi kriteria inklusi kemudian dilakukan analisa terhadap hasil kuesioner tersebut dengan menggunakan Uji Statistik Spearman Rank Test dengan menggunakan perangkat lunak atau SPSS.

HASIL

1. Data umum

A. Karakteristik Responden Berdasarkan Umur

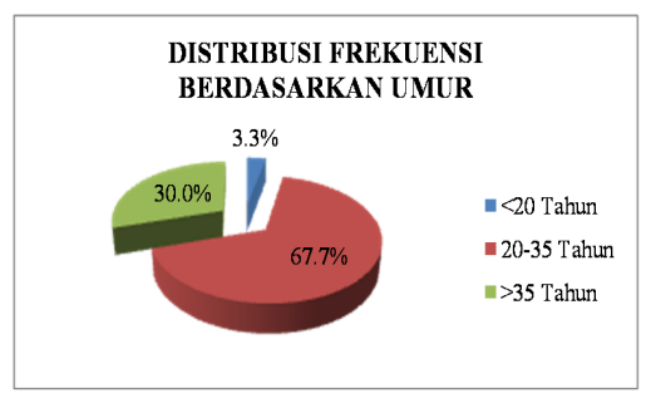

Diagram 1. Karakteristik Responden Berdasarkan Umur

Diagram 1 menunjukkan bahwa dari 30 responden umur ibu sebagian besar 20-35 tahun sebanyak 20 responden $(67,7 \%)$, umur $>35$ tahun sebanyak 9 responden $(30,0 \%)$, dan umur $<20$ tahun sebanyak 1 responden $(3,3 \%)$.

B. Karakteristik Responden Berdasarkan Pendidikan

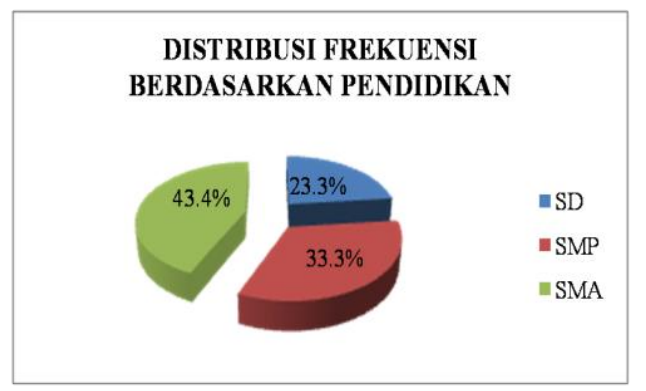

Diagram 2. Karakteristik Responden Berdasarkan Pendidikan

Diagram 2 menunjukkan bahwa dari 30 responden sebagian besar pendidikan SMA sebanyak 13 responden (43\%), pendidikan SMP sebanyak 10 responden (33,3\%), pendidikan SD sebanyak 7 responden $(23,3 \%)$.

C. Karakteristik Responden Berdasarkan Jenis pekerjaan

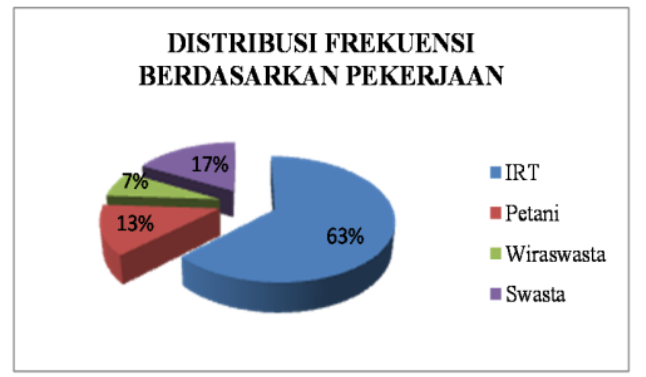

Diagram 3. Karakteristik Responden Berdasarkan Pekerjaan

Diagram 3 menunjukkan menunjukkan bahwa dari 30 responden sebagian besar ibu rumah tangga sebanyak 19 responden $(63 \%)$, pekerjaan swasta sebanyak 5 responden (17\%), pekerjaan petani sebanyak 4 responden $(13 \%)$, pekerjaan wiraswasta sebanyak 2 responden $(7 \%)$.

\section{Data Khusus}

A. Pengetahuan Ibu tentang Senam Hamil Tabel 1. Pengetahuan Ibu Hamil Tentang Senam Hamil

\begin{tabular}{llll}
\hline No & $\begin{array}{l}\text { Pengetahua } \\
\text {. }\end{array}$ & $\begin{array}{l}\text { Frekuens } \\
\text { i }\end{array}$ & $\begin{array}{l}\text { Persentas } \\
\text { e }\end{array}$ \\
\hline 1. & Baik & 22 & 73,3 \\
2. & Cukup & 6 & 20,0 \\
3. & Kurang & 2 & 6,7 \\
4. & Tidak baik & 0 & 0 \\
Jumlah & 30 & 100 \\
\hline
\end{tabular}


Tabel 1 menunjukkan menunjukkan bahwa dari 30 responden sebagian besar pengetahuan ibu tentang senam hamil adalah baik sebanyak 22 responden $(73,3 \%)$, dari pada pengetahuan cukup sebanyak 6 responden (20,0\%), pengetahuan kurang sebanyak 2 responden $(6,7 \%)$.

B. Minat Ibu Hamil dalam Melakukan Senam Hamil

Tabel 2. Minat Ibu Hamil Melakukan Senam Hamil

\begin{tabular}{llll}
\hline No. & Minat & Frekuensi & Persentase \\
\hline 1. & Minat & 21 & 70,0 \\
2. & Kurang & 7 & 23,3 \\
& Minat & & \\
3. & Tidak & 2 & 6,7 \\
& Minat & & \\
Jumlah & & 30 & 100 \\
\hline
\end{tabular}

Tabel 2 menunjukkan bahwa dari 30 responden sebagian besar responden berminat senam hamil yaitu sebanyak 21 responden $(70,0 \%)$, kurang minat sebanyak 7 responden $(23,3 \%)$, dan sebagian kecil responden tidak minat senam hamil sebanyak 2 responden $(6,7 \%)$.

C. Tabulasi Silang Hubungan pengetahuan Tentang Senam Hamil dengan Minat Ibu Hamil dalam Melakukan Senam Hamil

Tabel 3. Tabulasi Silang Hubungan Pengetahuan Tentang Senam Hamil dengan Minat Ibu Hamil dalam Melaksanakan Senam Hamil

\begin{tabular}{|c|c|c|c|c|c|c|c|c|c|}
\hline \multirow[t]{2}{*}{ No } & \multirow[t]{2}{*}{$\begin{array}{l}\text { Minat } \\
\text { Penge- } \\
\text { tahuan }\end{array}$} & \multicolumn{2}{|c|}{ Minat } & \multicolumn{2}{|c|}{$\begin{array}{l}\text { Rurang } \\
\text { Minat }\end{array}$} & \multicolumn{2}{|c|}{$\begin{array}{l}\text { Tidak } \\
\text { Minat }\end{array}$} & \multicolumn{2}{|c|}{ Total } \\
\hline & & $\mathrm{n}$ & $\%$ & $\mathrm{n}$ & $\%$ & $\mathrm{n}$ & $\%$ & $\mathrm{n}$ & $\%$ \\
\hline 'Y" & Bail & 16 & 472,2 & 5 & 22,7 & "Y" & 4,5 & 22 & 100 \\
\hline 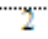 & Cukup & 4 & 66,7 & 1 & 16,7 & “产 & 16,7 & 6 & 100 \\
\hline 3 & Kurang & "Y" & 50,0 & 1 & 50,0 & 0 & 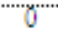 & 2 & 100 \\
\hline & "Total" & 21 & 70,0 & "n & $23 \cdot 3,3$ & 2 & 6,7 & 30 & 100 \\
\hline
\end{tabular}

dibandingkan kurang minat 1 responden $(16,7$ $\%)$ dan tidak minat 1 responden $(16,7 \%)$. Pengetahuan kurang dan minat baik 1 responden $(50 \%)$ sama besar dengan kurang minat 1 responden $(50 \%)$.

\section{Analisa Data}

Hasil analisa data dengan Rank Spearman's menggunakan SPSS diperoleh signifikasi (p) 0,010, tingkat kesalahan $(\alpha)$ 0,05 . Diketahui nilai $\mathrm{p}<\alpha$, berarti H1 diterima jadi kesimpulannya ada Hubungan
Pengetahuan tentang Senam Hamil dengan Minat Ibu Hamil dalam Melakukan Senam Hamil dengan nilai rho 0,461 maka tingkat hubungan tersebut positif sedang, berarti semakin tinggi pengetahuan tentang senam hamil maka semakin berminat melaksanakan senam hamil.

\section{PEMBAHASAN}

Data umum penelitian menunjukkan bahwa dari 30 responden berpengetahuan baik sebanyak 22 responden (73,3\%), memiliki pengetahuan yang cukup 6 responden (20,0\%), dan berpengetahuan kurang baik 2 responden $(6,7 \%)$. Pendidikan ibu sebagian besar SMA sebanyak 13 responden (43\%), umur ibu sebagian besar 20-35 tahun sebanyak 20 responden $(67,7 \%)$.

Faktor-faktor yang mempengaruhi pengetahuan diantaranya : pendidikan, pengalaman, umur, sosial ekonomi, kebudayaan, media masssa, sumber daya (Hurlock, 2012). Pengetahuan ibu sebagian besar baik yaitu berpendidikan SMA dan hal tersebut di pengaruhi oleh beberapa faktor salah satunya faktor pendidikan. Semakin tinggi tingkat pendidikan seseorang maka semakin mudah menerima informasi seputar kehamilannya.

Hal ini juga didukung oleh penelitian Anasari (2013) yang menunjukkan bahwa ada hubungan antara pengetahuan dengan minat ibu hamil dalam mengikuti senam hamil pvalue $=0.002(p<0.05)$. Penelitian Septiani (2019) juga menyebutkan bahwa pengetahuan merupakan hasil tahu yang merupakan interpretasi seseorang karena pengindraan terhadap suatu obyek. Pengetahuan manusia mayoritas diperoleh dari indra mata dan telinga. Pengetahuan merupakan area yang sangat penting untuk terbentuknya tindakan seseorang. Perilaku yang didasari oleh pengetahuan akan lebih bermakna dari pada perilaku yang tidak didasari pengetahuan (Notoadmodjo, 2010). Perilaku yang dimaksud adalah minat ibu hamil dalam melakukan senam hamil.

Penelitian Vioni (2011) juga menyatakan bahwa tingkat pengetahuan ibu hamil tentang senam hamil di RB Amanda menunjukkan kategori sedang $(47,5 \%)$, Hal ini menunjukkan bahwa pengetahuan ibu tentang senam hamil dapat meningkatkan keinginan ibu untuk mengikuti senam hamil dengan rutin. Pengetahuan baik ini masih dapat 
ditingkatkan lagi sehingga ibu hamil memiliki dasar pengetahuan yang kuat untuk melakukan senam hamil.

Sebagian besar responden berpengetahuan baik juga dipengaruhi oleh latar belakang usia yaitu pada rentang usia 20-35 tahun. Hal ini berarti perkembangan mental responden dalam kondisi baik, sehingga pengetahuan yang dimiliki tentang senam hamil juga baik.

Hasil penelitian juga menunjukkan bahwa minat ibu hamil dalam melakukan senam hamil didominasi oleh ibu hamil usia produktif dan berpendidikan cukup tinggi. Hal Ini sesuai dengan teori Hurlock (2012) bahwa faktor yang memiliki pengaruh minat dalam mengikuti senam hamil adalah umur, pendidikan, pekerjaan, pengalaman, tanggung jawab dan informasi. Ibu hamil yang berusia produktif biasanya memiliki stamina yang baik, sehingga semakin banyak informasi atau pengetahuan ibu hamil tentang pentingnya senam hamil dan untuk menuju kelahiran. Ibu hamil yang tidak bekerja juga memiliki waktu yang lebih banyak untuk mengikuti senam hamil dan menggali informasi tentang manfaat senam hamil maka akan semakin tinggi pula minat ibu hamil untuk melaksanakan senam hamil. Penelitian sebelumnya menyebutkan bahwa semakin tinggi minat mengikuti senam hamil pada ibu hamil maka akan semakin mendorong ibu hamil untuk melakukan senam hamil dengan rutin dan teratur (Masrurin, 2013).

Minat melaksanakan senam hamil harus ditimbulkan dengan cara menghadirkan keluarga pada saat konseling dan penyuluhan sehingga ibu hamil dalam melaksanakan senam hamil ada dukungan dan minat ibu tinggi dalam melaksanakan senam hamil.

Analisa data dengan menggunakan uji Rank Spearman dapat diketahui bahwa besarnya nilai $r=0,461$, ini menunjukkan hubungan yang positif sedang dengan menggunakan tingkat kepercayaan 95\% $(\alpha=0,05)$. Dengan signifikansi $p=0,010$, nilai ini menunjukkan bahwa nilai $\mathrm{p}<\alpha$. Hal ini berarti Ho ditolak dan $\mathrm{H} 1$ diterima yang artinya ada hubungan pengetahuan ibu hamil tentang senam hamil dengan minat ibu melaksanakan senam.

Hasil penelitian menunjukkan bahwa masih ada responden yang mempunyai pengetahuan kurang mengenai senam hamil yakni sebanyak 1 responden (50\%). Hal ini dikarenakan dukungan keluarga yang tidak ada, bahkan tidak mengijinkan ibu hamil melakukan senam hamil.

Pengetahuan seseorang sangat dipengaruhi oleh pendidikan yang dimilikinya, semakin baik pengetahuan seseorang terhadap sesuatu objek maka semakin baik pemahaman yang dimilikinya sehingga semakin mendukung proses berpikir. Kondisi ini dapat tercapai jika responden memperoleh informasi dan memiliki kemampuan yang baik dalam memahami informasi yang diperoleh serta memiliki daya dukung yang cukup untuk melaksanakan kegiatan sesuai dengan informasi yang diperoleh. Informasi cukup dan didukung oleh daya dukung yang memadai misalnya kemampuan menyediakan peralatan dan perlengkapan yang dibutuhkan, dan ini akan membuat ibu hamil dapat dengan baik melaksanakan senam hamil dengan baik.

Selain dari faktor pendidikan dan pekerjaan dibutuhkan pula faktor dukungan keluarga, dukungan institusi kesehatan, serta kesiapan mental ibu hamil dalam menerima kehidupan barunya sebagai ibu. Hal ini juga akan mempengaruhi pengetahuan ibu hamil tentang senam hamil dengan minat ibu dalam melaksanakannya.

Pengetahuan, kesiapan mental, dukungan emosional dari keluarga serta tenaga kesehatan yang baik maka minat ibu hamil dalam melaksanakan senam hamil juga akan tinggi.

\section{KESIMPULAN}

Ada hubungan atau korelasi positif sedang antara pengetahuan ibu hamil dengan minat ibu melaksanakan senam hamil, berarti semakin baik pengetahuan tentang senam hamil maka ibu hamil semakin berminat melakukan senam hamil.

\section{SARAN}

Berdasarkan hasil penelitian ini disarankan untuk lebih meningkatkan komunikasi atau konseling tentang pelaksanaan senam hamil dengan cara memberikan pengetahuan tentang senam hamil dimulai pada saat ibu hamil melakukan pemeriksaan Antenatal Care pada trimester II. Hal ini dimaksudkan untuk tercapainya program senam hamil yang dapat menunjang kesehatan ibu hamil dimana dengan latihan senam hamil otot khususnya, otot jalan lahir 
maka akan dapat memperlancar proses persalinan fisiologis. Selain itu tenaga kesehatan juga harus menghadirkan keluarga dalam memberikan konseling mengenai senam hamil karena keluarga merupakan orang terdekat ibu hamil.

\section{UCAPAN TERIMA KASIH}

Ucapan terima kasih kami sampaikan kepada pihak yang membantu terlaksananya penelitian ini yaitu PMB Ny. Lilik Muhibah, S.ST di Desa Sekaran Kecamatan Kayen Kidul Kabupaten Kediri.

\section{DAFTAR PUSTAKA}

Anasari, T. 2013. Analisis Faktor-faktor Yang Berhubungan Dengan Keikutsertaan Ibu Hamil dalam Melakukan Senam Hamil pada Kelas Ibu Hamil. Bidan Prada : Jurnal Publikasi Kebidanan Akbid YLPP Purwokerto

Hurlock, E.B. 2012. Psikologi Perkembangan Suatu Pendekatan Sepanjang Rentang Kehidupan. Jakarta : Erlangga

Kementerian Kesehatan Republik Indonesia. (2014). Profil Kesehatan Indonesia 2013. Jakarta

Jannah, N. 2012. Buku Ajar Asuhan Kebidanan Kehamilan. Yogyakarta: Andi

Juaria,H. 2018. Pendidikan dan Pekerjaan Ibu hamil terhadap Keikutsertaan Senam hamil. Jurnal Kebidanan Akademi Kebidanan Griya Husada. Vol.5 No.1

Manuaba, I.B. 2012. Buku Ajar Patalogi Obstetri Untuk Mahasiswa Kebidanan. Jakarta : EGC

Masrurin, D., Subiyatun,S. dan Rahmawati, N.I. 2013. Minat Ibu Hamil dalam Mengikuti Senam Hamil di BPRB Bina Sehat Bangunjiwo Kasihan Bantul. Jurnal Ners dan Kebidanan Indonesia. 1 (1) : 12-17

Notoatmodjo, S. 2010. Metode Penelitian Kesehatan. Jakarta : Rineka Cipta

Purwanto H. 2011. Pengantar Perilaku Manusia Untuk Keperawatan. Jakarta: EGC

Septiani, D.S. 2019. Faktor-Faktor Yang Berhubungan Dengan Minat Ibu hamil Dalam Mengikuti Senam hamil di RB Rhaudatunnadya. Manuskrip.

Vioni,A. 2011.Tingkat Pengetahuan Ibu Hamil tentang Senam Hamil di RB Amanda Gamping Sleman Yogyakarta. Skripsi. Stikes Alma Ata 